\title{
Non-Steroidal Anti-Inflammatory Drugs and Cognitive Function: Are Prostaglandins at the Heart of Cognitive Impairment in Dementia and Delirium ?
}

\author{
Colm Cunningham • Donal Thomas Skelly
}

Received: 11 July 2011 /Accepted: 29 August 2011 / Published online: 20 September 2011

(C) The Author(s) 2011. This article is published with open access at Springerlink.com

\begin{abstract}
Studies of non-steroidal anti-inflammatory drugs (NSAIDs) in rheumatoid arthritis imply that inflammation is important in the development of Alzheimer's disease (AD). However, these drugs have not alleviated the symptoms of $\mathrm{AD}$ in those who have already developed dementia. This suggests that the primary mediator targeted by these drugs, PGE2, is not actively suppressing memory function in $\mathrm{AD}$. Amyloid- $\beta$ oligomers appear to be important for the mild cognitive changes seen in $\mathrm{AD}$ transgenic mice, yet amyloid immunotherapy has also proven unsuccessful in clinical trials. Collectively, these findings indicate that NSAIDs may target a prodromal process in mice that has already passed in those diagnosed with $\mathrm{AD}$, and that synaptic and neuronal loss are key determinants of cognitive dysfunction in $\mathrm{AD}$. While the role of inflammation has not yet become clear, inflammatory processes definitely have a negative impact on cognitive function during episodes of delirium during dementia. Delirium is an acute and profound impairment of cognitive function frequently occurring in aged and demented patients exposed to systemic inflammatory insults, which is now recognised to contribute to longterm cognitive decline. Recent work in animal models is beginning to shed light on the interactions between systemic inflammation and CNS pathology in these acute exacerbations of dementia. This review will assess the role of prostaglandin synthesis in the memory impairments observed in dementia and delirium and will examine the relative contribution of amyloid, synaptic and neuronal loss.
\end{abstract}

C. Cunningham $(\bowtie) \cdot$ D. T. Skelly

School of Biochemistry and Immunology \& Trinity College

Institute of Neuroscience, Trinity College Dublin,

Dublin, Republic of Ireland

e-mail: colm.cunningham@tcd.ie
We will also discuss how understanding the role of inflammatory mediators in delirious episodes will have major implications for ameliorating the rate of decline in the demented population.

Keywords Dementia - Delirium · Cyclooxygenase · Prostaglandin $\cdot$ Microglia $\cdot$ Memory $\cdot$ Learning .

Alzheimer's disease

\section{Introduction}

There is a long-running debate in Alzheimer's disease (AD) research as to why long-term treatment with non-steroidal anti-inflammatory drugs (NSAIDs) very significantly protects against the subsequent development of $\mathrm{AD}$ but treatment of AD patients with NSAIDs offers no relief for those already experiencing the devastating memory loss associated with this disease. This review takes as its starting point the position that if NSAIDs offer no relief to patients with $\mathrm{AD}$ then it is reasonable to conclude that the observed memory dysfunction is not attributable to a direct inhibition of memory processes by prostaglandins, the primary target of these drugs. If NSAID dosing is appropriate to reduce prostaglandin levels, but does not ameliorate memory function then it is unlikely that prostaglandins are actively interfering with memory in these patients. This, of course, does not rule out the possibility that long-term exposure to prostaglandins may influence the deposition or clearance of amyloid- $\beta(A \beta)$ or may result in significant damage, the accumulation of which may impair memory function. However, it appears that reducing prostaglandins in the short term is not helpful. This appears contradictory to multiple pre-clinical studies in which NSAIDs protected against cognitive impairments in $\mathrm{AD}$ transgenic mice that 
might have suggested a straightforward relationship between cyclooxygenase (COX) activity and memory function. In addition, there is clear evidence from the neuroinflammation field that prostaglandins can directly impair memory function. Why, then, have these treatments failed to offer any protection in AD patients? In this review we attempt to examine the roles of COX and PGE2 in memory function, both physiologically and pathologically, and address the very substantial contribution neuronal and synaptic loss makes to the burden of memory deficits in $\mathrm{AD}$.

\section{Interogating the key determinants of cognitive dysfunction in $\mathrm{AD}$}

Figure 1 shows a simple scheme summarising the major proposed contributors to cognitive dysfunction in $\mathrm{AD}$ and in the proceeding section we will attempt to look at the likely contribution of each of these facets of pathology to cognitive dysfunction in $\mathrm{AD}$, based on what animal models have shown us. It is clear that progressing disease, in humans with $\mathrm{AD}$, induces robust synaptic and neuronal loss, both of which would be predicted to induce cognitive deficits. $A \beta$ deposition and inflammation are also features of disease and there is evidence that each of these factors can induce cognitive deficits. The majority of research in elucidating the molecular mechanisms of memory impairment in $\mathrm{AD}$ has come from transgenic mouse models. The hallmark cognitive deficit of patients with $\mathrm{AD}$ is a failure of episodic memory and though recent studies have now made innovative efforts at examining this in rats (Iordanova et al. 2009) and have described similar 'episodic-like' memory deficits in Tg2576 mice (Good and Hale 2007), there have not yet been any mechanistic studies addressing molecular mechanisms of such deficits. However, a number of different cognitive tasks with some validity for $\mathrm{AD}$ have been assessed in mice and it is interesting to examine these with respect to the four possible pathological culprits in Fig. 1.

\section{Working memory}

Working memory deficits in T-maze alternation tasks are the most frequently reported deficit in the $\mathrm{Tg} 2576$ mouse (Stewart et al. 2011) and are present in most widely used $A \beta$-inducing transgenics (Chapman et al. 1999; Corcoran et al. 2002; Barnes et al. 2004; Caccamo et al. 2007; Cacucci et al. 2008; Frye and Walf 2008; Filali and Lalonde 2009). These models have all been described to show marked amyloidosis and although there is some evidence of neuronal and synaptic loss and disassembly, it has been striking how limited neuronal pathology is in these models compared to that observed in human AD (Wirths and Bayer 2010). This

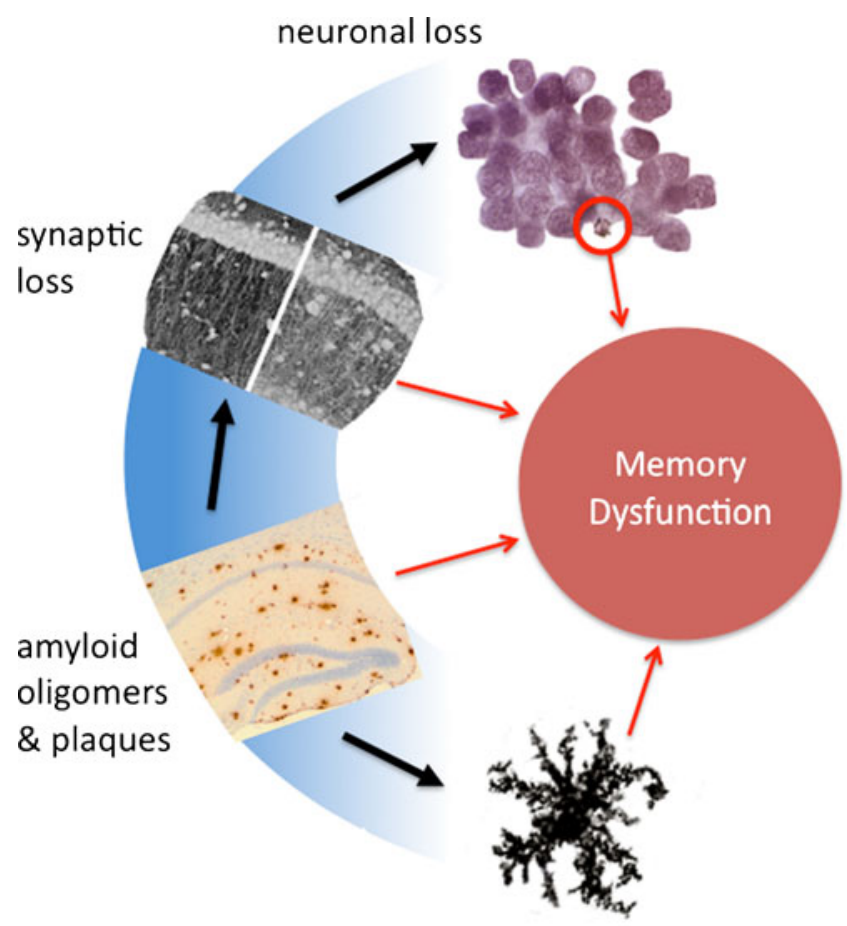

microglial activation

Fig. 1 Potential contributors to cognitive dysfunction in Alzheimer's disease. It is known from experimental psychology and neuropathology studies that neuronal and synaptic loss in the cortices and hippocampus (both of which are prominent in AD) induce cognitive impairments. The generation of amyloid plaques and of oligomeric $\mathrm{A} \beta$ species occurs progressively during $\mathrm{AD}$ and there is clear evidence that at least the latter contribute to cognitive impairments seen in $\mathrm{AD}$ transgenic mice. Though linked by arrows, it is not proven that synaptic loss and neuronal loss are caused by amyloidosis. Microgliosis is apparent in AD and in transgenic models. Though microglia surround plaques in transgenic models, microgliosis is also an inevitable consequence of neuronal death and thus may be different in models and in human AD. Neuroinflammation is widely described as inducing cognitive deficits but it is difficult to extricate this from direct effects of amyloid in animal models, and whether microglia produce cognitively significant levels of prostaglandins remains unclear despite the many NSAID studies of AD transgenics. Thus early stage cognitive deficits in $\mathrm{AD}$ transgenics, and perhaps in $\mathrm{AD}$ patients, maybe caused by $\mathrm{A} \beta$ with or without some contribution from inflammatory responses

indicates that the presence of $A \beta$ peptides is sufficient to produce working memory dysfunction in the absence of neuronal or synaptic loss. This must be clearly distinguished from synaptic dysfunction, for which there is robust evidence. There is a very substantial literature on glutamate receptor alterations and electrophysiological disruption and caused by oligomeric species of $\mathrm{A} \beta$ (Shankar and Walsh 2009) but this is beyond the scope of the current review. Despite any non-reliance of these T-maze deficits on synaptic loss in the models so far studied, robust synaptic loss in the CA1 of the hippocampus is sufficient, of itself, to produce similar working memory deficits, as we have shown in the 
ME7 model of prion disease (Guenther et al. 2001; Cunningham et al. 2003). Importantly, this synaptic loss precedes neuronal loss (Cunningham et al. 2003) so we can separate the contribution of these two elements of degeneration. Of course, neuronal loss in the same structure also produces these deficits, as shown in several hippocampal ablation studies (Bannerman et al. 1999, 2002). However, CNS inflammatory mediator production, induced by $200 \mu \mathrm{g} / \mathrm{kg}$ LPS intraperitoneally, fails to produce any deficit on this task (Murray et al. 2010) and there are no demonstrations, to our knowledge of non-neurotoxic doses of inflammogens impairing T-maze alternation.

\section{Visuospatial reference memory}

We can pursue a similar line of enquiry with respect to visuospatial reference memory deficits in the Morris Water Maze (MWM). This is the most commonly assessed form of memory in $\mathrm{AD}$ transgenics and deficits have consistently been reported in this task. However, these deficits vary in magnitude and time of onset, vary according to background strain (Glazner et al. 2010) and have not been reported by all laboratories (King and Arendash 2002). A recent metaanalysis of multiple studies with $\mathrm{Tg} 2576$ reported that when performance of control animals expressing human APP without the Swedish mutation is taken into account, this effect only becomes apparent between 12 and 18 months and requires large numbers of animals (Reed et al. 2010). It is also important to point out that $\mathrm{AD}$ transgenic mice can actually learn this MWM task: they simply learn it more slowly than wild-type controls (Kotilinek et al. 2002). Performance in the MWM is well known to require intact hippocampal function (Morris et al. 1982) and thus synaptic and neuronal loss in the hippocampus obviously impair its function. The question of whether inflammation can also affect performance of this task is more complicated. Multiple studies have reported deficits in this task after administration of LPS or IL- $1 \beta$ while others have not noted deficits (Cunningham and Sanderson 2008). However, the task is ill-suited to assessment of cognition in animals that are experiencing the reduced motivation, elevated stress and anxiety, and compromised locomotor function that are features of the sickness response. Measures of latency, distance travelled to find the hidden platform, analysis of route taken and appropriate probe trials must all be examined to correctly distinguish cognitive impairments from emotional and performance deficits that may appear as cognitive deficits, as has been reviewed in detail elsewhere (Cunningham and Sanderson 2008). Careful analysis of these data suggests that inflammatory stimulation does not robustly produce cognitive deficits on this visuospatial reference task. This is an important point because these studies of inflammation and MWM performance, coupled with the impact of NSAIDs in AD transgenics, are usually cited as key evidence that products of inflammation may explain the deficits observed in AD. Neuroinflammation produced by the intracerebroventricular infusion of LPS can induce lasting cognitive deficits in the MWM (Hauss-Wegrzyniak et al. 1998) However this inflammation is more severe than that observed in transgenic models of $\mathrm{AD}$ and since this chronic LPS treatment also induces death of CA3 pyramidal neurons it is difficult to separate the cognitive effects of neuroinflammation and cognitive effects of neuronal death. Nonetheless, here are numerous reports that anti-inflammatory treatments ameliorate cognitive dysfunction in $\mathrm{AD}$ transgenics so it is necessary to address whether these drugs have successfully targeted inflammatory mediators or have affected other targets.

\section{NSAIDs in AD transgenic mice}

The evidence that prostaglandins do have some deleterious effects in learning and memory is relatively clear: direct application of PGE2 to the brain results in working memory deficits in a runway task (Matsumoto et al. 2004) and has also been shown to impair contextual fear-conditioning (Hein et al. 2007). Furthermore there is evidence that COX2-overexpression can impair neuronal function. Aged animals over-expressing neuronal COX-2 display behavioural deficits and neuronal loss (Andreasson et al. 2001) and female $\mathrm{AD}$ double transgenics over-expressing COX-2 have behavioural deficits that are abrogated by COX inhibition (Melnikova et al. 2006), although the sexspecificity of the latter findings makes them less compelling. Thus, PGE2, the major target of NSAIDs, can impair memory function but are prostaglandins key players in the memory deficits seen in $\mathrm{AD}$ transgenics and in $\mathrm{AD}$ patients? In a number of models of AD, NSAIDs have been applied with beneficial effects. A number of studies have shown amelioration of cognitive deficits in $\mathrm{AD}$ transgenic mice after long-term treatment (months) with flurbiprofen (Kukar et al. 2007), ibuprofen (Lim et al. 2001; Kotilinek et al. 2008), naproxen and MF-tricyclic (Kotilinek et al. 2008), and COX-1-specific trifusal (Coma et al. 2010). Long-term treatment with ibuprofen or, to a lesser degree, indomethacin and other COX-1/2 inhibitors can also reduce $A \beta$ plaque load, $A \beta 1-42$ levels or $A \beta$ 42:40 ratios in the hippocampus and cortex ( $\mathrm{Lim}$ et al. 2000; Yan et al. 2003; Heneka et al. 2005; Morihara et al. 2005; Kukar et al. 2007; McKee et al. 2008; Coma et al. 2010). Most of these drugs show some selectivity towards COX-1. However, the relationship between COX inhibition, prostaglandin reduction and cognitive improvement has not been carefully examined within these studies. Morihara et al. (2005) suggested that ibuprofen, via effects on IL-1 expression, decreased antichymotrypsin levels, thus 
reducing plaque load and Lim et al. (2001) and Sung et al. (2004), also showed decreased NFKB activation/IL-1 $\beta$ expression. In those studies where PGE2 was assessed it appears that NSAID treatment does generally decrease prostaglandin levels, but that neither PGE2 nor the enzymes COX-1 and COX-2 showed significant disease-related elevation in the transgenic mouse models used (Quinn et al. 2003; Sung et al. 2004; Kotilinek et al. 2008). Where levels have been examined, those inhibitors with preferential inhibition of COX-1 have decreased PGE2 levels more effectively than COX-2 selective inhibitors (Sung et al. 2004). No studies, to our knowledge have shown that PGE2 is elevated in $\mathrm{AD}$ transgenics and is reduced by treatment with COX inhibitors, with a resulting improvement in cognitive function. Therefore, a straightforward relationship between PGE2 production and memory impairment cannot be deduced from these studies despite the propensity of COX inhibition to ameliorate these deficits.

It is also clear that there are 'off-target' effects of NSAIDs, affecting relevant inflammatory and amyloidogenic pathways. We mention some of these possibilities here for completeness but comprehensive discussion of these topics is beyond the scope of this review. These have been reviewed previously (Weggen et al. 2007; Landreth et al. 2008). Indomethacin, ibuprofen and diclofenac all act as agonists for peroxisome proliferator-activated receptor- $\gamma$ (PPAR $\gamma)$. This nuclear receptor is a potent down-regulator of NFKB activation and its targeting has had beneficial effects in AD models (Lehmann et al. 1997; Combs et al. 2000; Landreth and Heneka 2001). Thus, the inhibition of aspects of microglial function, such as IL- $1 \beta$ synthesis (Heneka et al. 2005), seems more likely to occur via this pathway than via prostaglandin inhibition. In addition, a subset of NSAIDs including sulindac sulphide, ibuprofen and indomethacin, but not including naproxen, aspirin or selective COX-1 and COX-2 inhibitors SC-560 or celecoxib, lower $A \beta 1-42$ independently of their impact on COX activity (Weggen et al. 2001). This raised the possibility that the effectiveness of NSAIDs in the population may not be related to its effects on limiting prostaglandin production. One recent study has examined prostaglandins, cytokines, $A \beta 1-42$ and cognitive effects in a single study. Kotilinek et al. (2008) showed that ibuprofen, naproxen and a tricyclic COX-2-specific drug all restored memory function in $\mathrm{Tg} 2576$ mice and reversed impairments of long-term potentiation (LTP) induced by acute application of $A \beta$ These effects were independent of effects on $\mathrm{A} \beta 42$ and of effects on pro-inflammatory cytokines. The authors reported that all effective drugs shared a COX-2 inhibitory profile and that improved memory function correlated with lower PGE2 levels. However, both COX-2 mRNA and PGE2 levels were lower in transgenics than in wild-type mice and were not affected by the drug treatment. Thus while this study refocuses attention on prostaglandins, the relationship between PGE2, COX expression and memory dysfunction remains very unclear.

Furthermore, the impact of NSAIDs in animal models of $\mathrm{AD}$ has generally been assessed by long-term treatment before any cognitive assessment. Therefore, the effect of blocking inflammation and/or amyloidogenesis across a number of weeks/months before cognitive testing has been examined, and the ability of these drugs to lift the active suppression of memory function by inflammatory mediators has not. In contrast, there is evidence for rapid reversal of cognitive dysfunction when $A \beta$ is directly targeted using monoclonal antibodies in the $\operatorname{Tg} 2576$ (Kotilinek et al. 2002) or PDAPP (Dodart et al. 2002) strains. Collectively these data suggest that some oligomeric species of $A \beta$ is directly impacting on memory in these mild cognitive impairment or 'prodromal' models of $\mathrm{AD}$ and indeed there is now good evidence for such direct impacts of $A \beta$ oligomers on hippocampal physiology (Walsh et al. 2002). In contrast, the recent amyloid immunization clinical trial demonstrates that even very successful removal of amyloid plaques offers no relief to $\mathrm{AD}$ patients: all patients followed-up after the AN1792 study died with terminal dementia and an MMSE of zero (Holmes et al. 2008). Therefore, NSAIDs and immunization effects in the animal models may differ from their effects in $\mathrm{AD}$ patients and one must make a comparison between the pathological aspects in these models and those in the diseased patients who we know are not protected by these drugs once impairments are apparent (Fig. 2). Most animal models of AD show limited neuronal and synaptic loss (Wirths and Bayer 2010) and this is in sharp contrast to the devastating losses incurred during $\mathrm{AD}$ progression: entorhinal cortex and hippocampus show up to $50 \%$ pyramidal cell loss (Hyman et al. 1984) and there are very significant losses of basal forebrain cholinergic (Davies and Maloney 1976; Whitehouse et al. 1981, 1982) and locus coeruleus noradrenergic neurons (Tomlinson et al. 1981). In addition, synaptic loss is very marked and correlates better with cognitive dysfunction than any other pathological feature including plaque burden (Terry et al. 1991).

While animal models show that amyloid overproduction can produce cognitive deficits, even the originators of the first animal models of AD now suggest that these models probably represent a stage of disease that resembles mild cognitive impairment (MCI) or perhaps even earlier (Ashe and Zahs 2010). Thus it is possible that NSAIDs in AD transgenics are targeting a process that does not occur or has already passed when these drugs are administered to patients with AD. This timing issue could explain the discrepancy between beneficial effects of NSAIDs in models and patients. There is limited evidence that NSAIDs are beneficial at early stages 


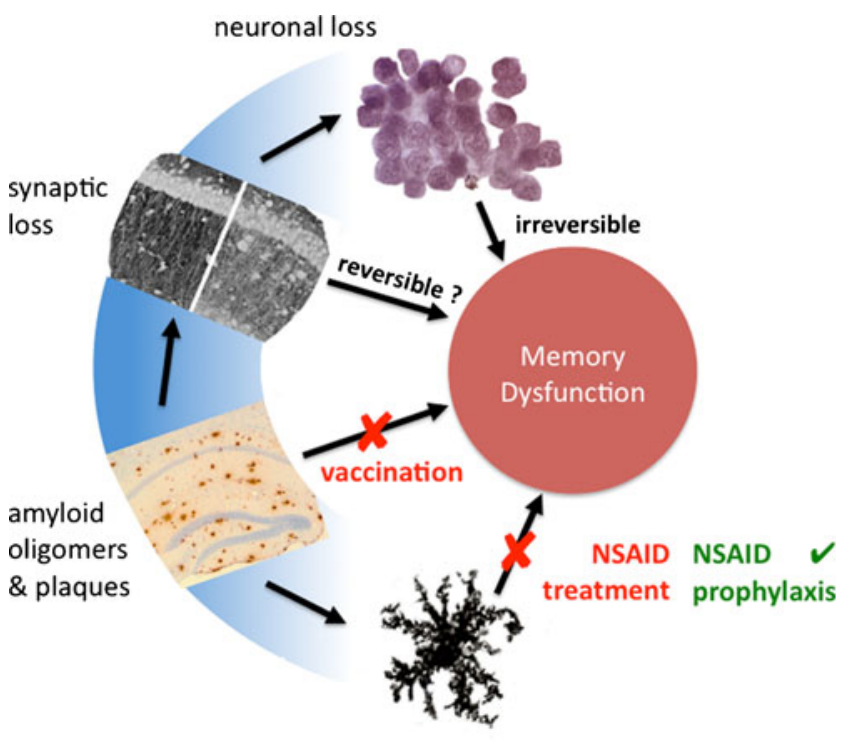

microglial activation \& prostaglandin synthesis

Fig. 2 Key determinants of cognitive dysfunction. Evidence of the contribution of different features of pathology to memory dysfunction in $A D$. Successful removal of $A \beta$ plaques failed to improve or halt cognitive decline in AD patients. Likewise, NSAID treatment, while successful as a long-term preventative strategy, was unsuccessful as a treatment for established AD. Synaptic loss contributes to cognitive decline and may, to some extent, be plastic/reversible. Neuronal loss is irreversible and its progression will inevitably lead to cognitive decline. This suggests that later stage cognitive decline in $\mathrm{AD}$ is likely to be chiefly caused by synaptic and neuronal loss

in $\mathrm{AD}$ transgenics but showed no benefits when treatment is initiated later in progression (Kukar et al. 2007). Therefore the question arises: have animal models of $\mathrm{AD}$ demonstrated that prostaglandins are not important in the evolution of cognitive deficits, or have we failed to examine, in sufficient detail, which enzymes synthesise which prostanoids in which compartment at which time? In order to rationalise the success or failure of these treatments in $\mathrm{AD}$ one also needs to look in considerably more detail at the primary targets of NSAIDs: COX isoforms.

\section{Cyclooxygenases in disease and cognition}

COXs are the essential and rate-limiting enzyme in the synthesis of prostaglandins from arachidonic acid. PGG2 is initially synthesized via the bis-oxygenase activity of COX, followed by generation of PGH2 via the peroxidase activity. This is then the starting point for a number of other synthase enzymes to synthesize a wide spectrum of prostanoids, the production of all of which would be affected by COX inhibition (Fig. 3). It is now well accepted, from epidemiological studies and meta-analyses thereof, that inhibition of these enzymes with NSAIDs significantly protects against the subsequent development of AD (McGeer et al. 1996; In 'T Veld et al. 2001; Etminan et al. 2003; Vlad et al. 2008). However, the resulting clinical trials have consistently failed to demonstrate beneficial effects in terms of treatment or prevention (Aisen et al. 2003; Lyketsos et al. 2007; Martin et al. 2008). These findings demand not just a better appreciation of the temporal and neuroanatomical aspects of COX-1 and COX-2 activation in disease but also of the normal roles of these enzymes in memory and learning.

Two major isoforms of COX have been described, COX-1 and COX-2, which appear to differentially affect inflammation, blood flow, cell death and fever in the CNS (Bosetti 2007). Both COX-1 and COX-2 are constitutively expressed in the CNS; COX-1 is primarily expressed in microglia and some neuronal populations (Yermakova et al. 1999; Hoozemans et al. 2001) and has recently been shown in perivascular macrophages (PVMs) in rodents (Garcia-Bueno et al. 2009). COX-2 is readily detected in neurons in many brain regions, both in humans and in rodents (Yasojima et al. 1999; Hoozemans et al. 2001). Given that COX-2 is readily induced by inflammatory stimuli in microglia and endothelium (Ek et al. 2001; Uchikado et al. 2004), it has often been the pharmacological target of choice against neuroinflammation. However, the evidence that COX-2 increases as a function of progression of $\mathrm{AD}$ is rather limited. It has been described to be elevated at early stages of disease but later decreases (Hoozemans et al. 2001). There are early reports of elevated PGE2 in AD patients with respect to controls (Montine et al. 1999), but one longitudinal study reported early elevated PGE2 followed by declining levels as memory declined (Combrinck et al. 2006). Importantly, higher PGE2 levels also predicted longer survival. These data may be consistent with an early inflammatory response, but also suggest that there is an important role for COX-2 derived PGE2 in maintenance of memory function. There is increasing evidence that constitutive, neuronal COX-2 function is essential for normal hippocampal function. Specific inhibition of basal COX-2 activity was shown to inhibit memory consolidation in Morris Water Maze experiments (Teather et al. 2002) and later experiments repeated this and showed that COX-1 inhibition did not impair memory function (Cowley et al. 2008). Mechanistically, there is evidence that PGE2, released from post-synaptic dendritic spines can bind pre-synaptic prostaglandin receptors EP2 and/or EP4 and increase the amplitude of stimulus-evoked excitatory post-synaptic potentials (EPSPs) in the hippocampus (Sang et al. 2005). This facilitatory role of basal COX-2 derived prostaglandins is dependent on the activity of cAMP-dependent protein kinase (Chen and Bazan 2005), the primary signalling pathway induced by EP2 and EP4 receptor activation. Thus with respect to memory function there are good reasons to believe that inhibition of COX-2 activity would be deleterious. Given these findings, the 
Fig. 3 Prostanoid synthesis and action. The prostanoids originate from the release of arachadonic acid from membrane phospholipids by phospholipase A2. AA is subjected to bisoxygenase and peroxidase activities of the cyclooxygenases (or prostaglandin $\mathrm{G} / \mathrm{H}$ synthases) to form PGG2 and then PGH2. PGH2 is the substrate for the synthases PGE2 synthase, PGD2 synthase, prostacyclin synthase, PGF2a synthase (PGF2a can also be synthesized directly from PGE2) and thromboxane synthase to synthesize the individual classes of prostanoids. These classes all have discrete receptor subtypes through which they initiate their actions. The cyclooxygenases 1 and 2 are the primary targets of NSAIDs but these may be specific for one isoform or another, selective, or nonselective. Blocking the production of $\mathrm{PGH} 2$ via $\mathrm{COX}$ inhibition can reduce the levels of all downstream prostanoids

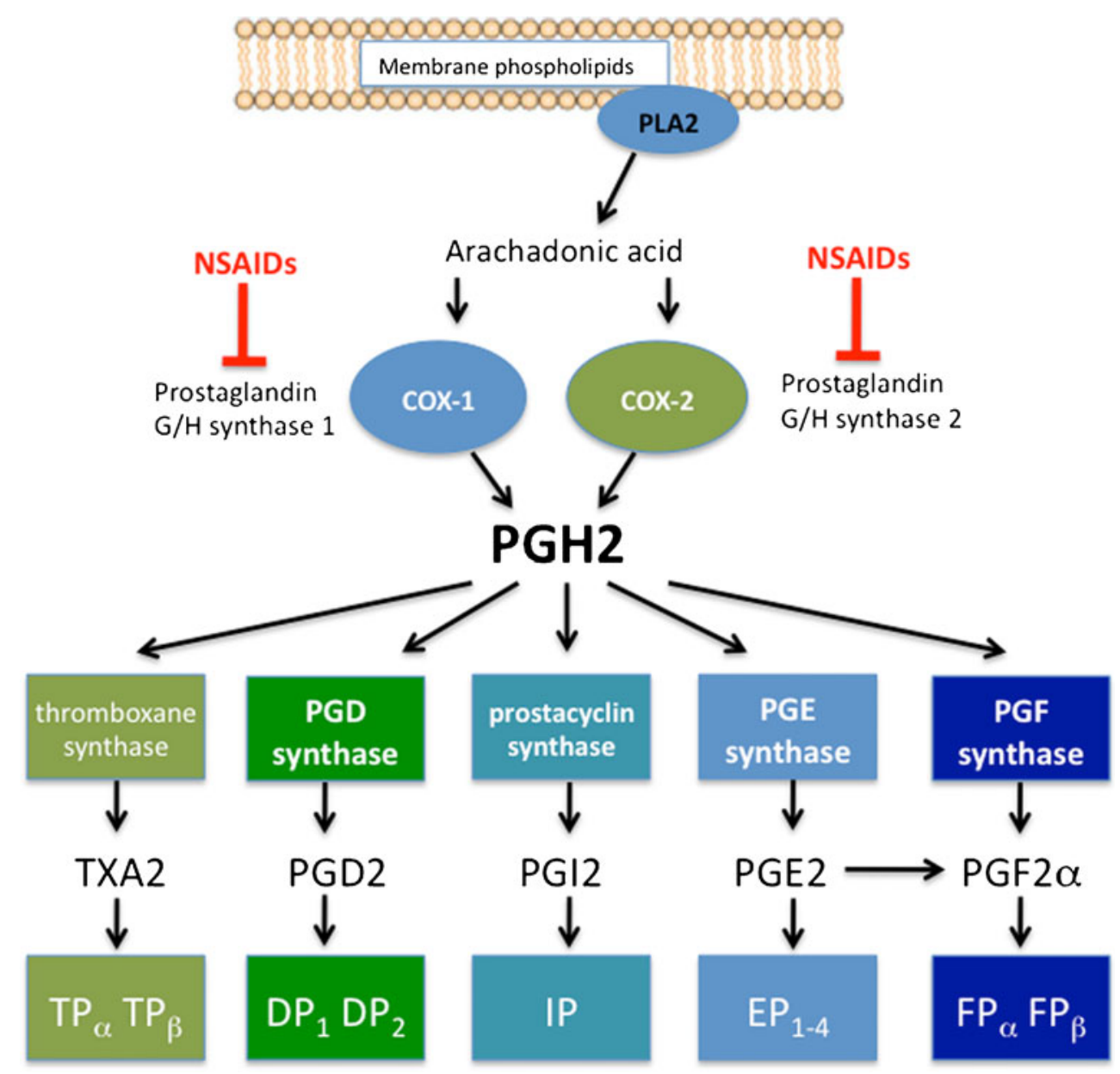

number of clinical trials that have used drugs selectively targeting COX-2 is rather surprising (Aisen et al. 2002, 2003; Reines et al. 2004; Lyketsos et al. 2007; Soininen et al. 2007; Aisen et al. 2008; Leoutsakos et al. 2011).

Conversely COX-1, while generally regarded as constitutively active and not induced by inflammation, is increased in a number of neurodegenerative diseases including AD (Yermakova et al. 1999; Hoozemans et al. 2001) prion disease (Deininger et al. 2003) and HIV dementia (Griffin et al. 1994). Furthermore the hypothesis that COX-1 is central to mediating the neuroinflammatory response has been gaining support in the literature (Choi et al. 2009). Pharmacological inhibition or genetic deletion of COX-1 reduces LPS and $\beta$-amyloid-induced neuroinflammation including reduced levels of NFkB-mediated proinflammatory cytokine synthesis and decreased histological evidence of microglial activation (Choi et al. 2008; Choi and Bosetti 2009). Recent cognitive studies show that in a model chronic of CNS IL-1 over-expression that COX-1-generated PGE2 produces deficits in contextual fear conditioning (Matousek et al. 2010). With respect to CNS consequences of systemic inflammation, it has been shown that COX-1selective inhibition protects against LPS-induced behavioural depression while the COX-2 specific nimesulide does not (Teeling et al. 2010). Our own recent work shows that selective COX-1 inhibition can protect against LPS-induced working memory deficits on a background of chronic neurodegenerative disease (Skelly \& Cunningham, unpublished data) and there is emerging evidence that COX-1positive PVMs may be a key interface between systemic and CNS inflammation (Garcia-Bueno et al. 2009). It is clear that exogenously added or pathologically elevated PGE2 can impair memory function in fear conditioning (Hein et al. 2007; Matousek et al. 2010) and runway tasks (Matsumoto et al. 2004) and thus inhibition of COX-1 might be protective in situations in which the levels of this enzyme and resulting prostanoids have become elevated by pathology or acute inflammatory stimulation. The important, but overlooked, role of systemic inflammation in AD-related cognitive decline is discussed below.

\section{Inflammation exacerbates dementia: delirium}

Despite the ongoing uncertainty about the role of inflammation in cognitive dysfunction in dementia, it is absolutely 
clear that acute inflammatory insults do produce cognitive impairment in cases of delirium during dementia. Despite the complete neglect of this area by basic researchers in $\mathrm{AD}$, understanding the mechanisms of this acute cognitive impairment is likely to contribute to our understanding of how inflammation alters cognition in clinical practice, where patients with dementia frequently suffer comorbidities including systemic infections, injuries and surgeries. Delirium is an acute and profound impairment of consciousness and cognitive function (Burns et al. 2004; Meagher 2009). It is well established that aging and dementia are the major risk factors for episodes of delirium (Fick et al. 2002) and systemic inflammatory episodes are among the major triggers (MacLullich et al. 2008). Significantly, the occurrence of delirium is known to produce long-term cognitive impairments and to be associated with more rapid progression of dementia (Rockwood et al. 1999; Rahkonen et al. 2000; Fong et al. 2009). Therefore, if systemic inflammation frequently induces delirium in the demented population and this accelerates dementia then identification of the inflammatory mediators responsible for these episodes would be predicted to be therapeutic targets also in dementia per se. However, inhibition of such targets would not be predicted to offer immediate relief in dementia, rather the positive effects could only be appreciated across a relatively long period of treatment during which the negative CNS consequences of systemic inflammation would be blocked. This is consistent with the efficacy of NSAIDs to protect against development of dementia but their inability to treat established disease. There is a growing body of evidence that systemic inflammation (induced by LPS, poly I:C or chronic systemic expression of IL-1 $\beta$ ) can accelerate progression and/or exacerbate features of pathology in a number of animal models of neurodegenerative disease including amyotrophic lateral sclerosis (Nguyen et al. 2004), prion disease (Cunningham et al. 2005, 2009; Field et al. 2010), 3xTg-AD (Kitazawa et al. 2005), tau pathology (Lee et al. 2010), APP/PS1 (Sheng et al. 2003) and Parkinson's Disease (Pott Godoy et al. 2008; Villaran et al. 2010). Furthermore, that systemic inflammation accelerates cognitive decline has also now been demonstrated in AD patients (Holmes et al. 2009). Consistent with the idea of a dementia/delirium continuum we have shown that repeated systemic inflammatory challenges superimposed on advancing disease induce acute dysfunction followed by recovery, but with each successive challenge the acute exacerbation is more severe and less recoverable (Field et al. 2010). It has been apparent for some time that systemic LPS can alter amyloid processing (Brugg et al. 1995; Sly et al. 2001; Sheng et al. 2003; Lee et al. 2010), but it is now clear that systemic inflammation, particularly in the presence of microglia primed by prior pathology, can induce a significant exacerbation of CNS inflammation, causing de novo inflammatory damage. Such damage may occur via iNOS, TNF- $\alpha$, IL- $1 \beta$, prostaglandins and many other pathways (Fig. 4). These pathways merit considerably more investigation in dementia but are beyond the scope of this review and have recently been reviewed elsewhere (Perry 2010; Cunningham 2011).

With respect to the delirious episode itself, there have been a number of studies associating pro-inflammatory cytokines with the occurrence of delirium after hip fracture or hip replacement surgery and these studies have consistently implicated IL-6, IL-8 and others (Beloosesky et al. 2007; van Munster et al. 2008, 2010; Maclullich et al. 2011). However, causation cannot be established in such association studies. Thus, there is a need for animal model studies of delirium. We have recently developed the first animal model of delirium during dementia, employing the superimposition of systemic LPS $(100 \mu \mathrm{g} / \mathrm{kg})$ on a background of chronic progressive neurodegenerative disease, using the ME7 model of prion disease (Murray et al. 2010). These LPS challenges produce acute and reversible working memory deficits in animals with prior chronic neurodegenerative disease, but not in normal animals challenged with LPS. This T-maze alternation working memory deficit has good validity for clinical delirium since the task is reliant on attention to the initially sampled arm and short-term memory retention which are key features of the delirious episode as defined by DSM IV and WHO ICD-10 definitions (WHO 1992; APA 1994). In addition, deficits are of acute onset and are transient, key diagnostic criteria for delirium (Inouye et al. 1990).

There also exist somewhat similar studies in aging rodents. Johnson and colleagues have shown working memory deficits that consist of a reduced ability of LPS-treated aged animals to learn the new location of a hidden platform which is moved each day of testing, compared to aged or LPS-treated alone (Chen et al. 2008). Barrientos et al. (2009), have shown in a series of studies that infection with $E$. coli in aged animals induces impairments of consolidation of new memories in contextual fear conditioning experiments. These latter studies implicated central IL-1 $\beta$ in this process (Frank et al. 2010). The microglial priming hypothesis, whereby microglia are primed by neurodegeneration (Cunningham et al. 2005) or aging (Godbout et al. 2005) to show an exaggerated CNS IL-1 $\beta$ response to systemic inflammatory stimulation, has been used to explain most of these findings on selective memory deficits in neurodegeneration/aging (Fig. 4), although this still requires further proof. In related studies on postoperative cognitive dysfunction IL- $1 \beta$ and TNF- $\alpha$ have been implicated in a failure to consolidate new memory for spatial context following an inflammatory surgical insult (Cibelli et al. 2010; Terrando et al. 2010). Using the T-maze task described above, we have recently shown that the selective 
Periphery

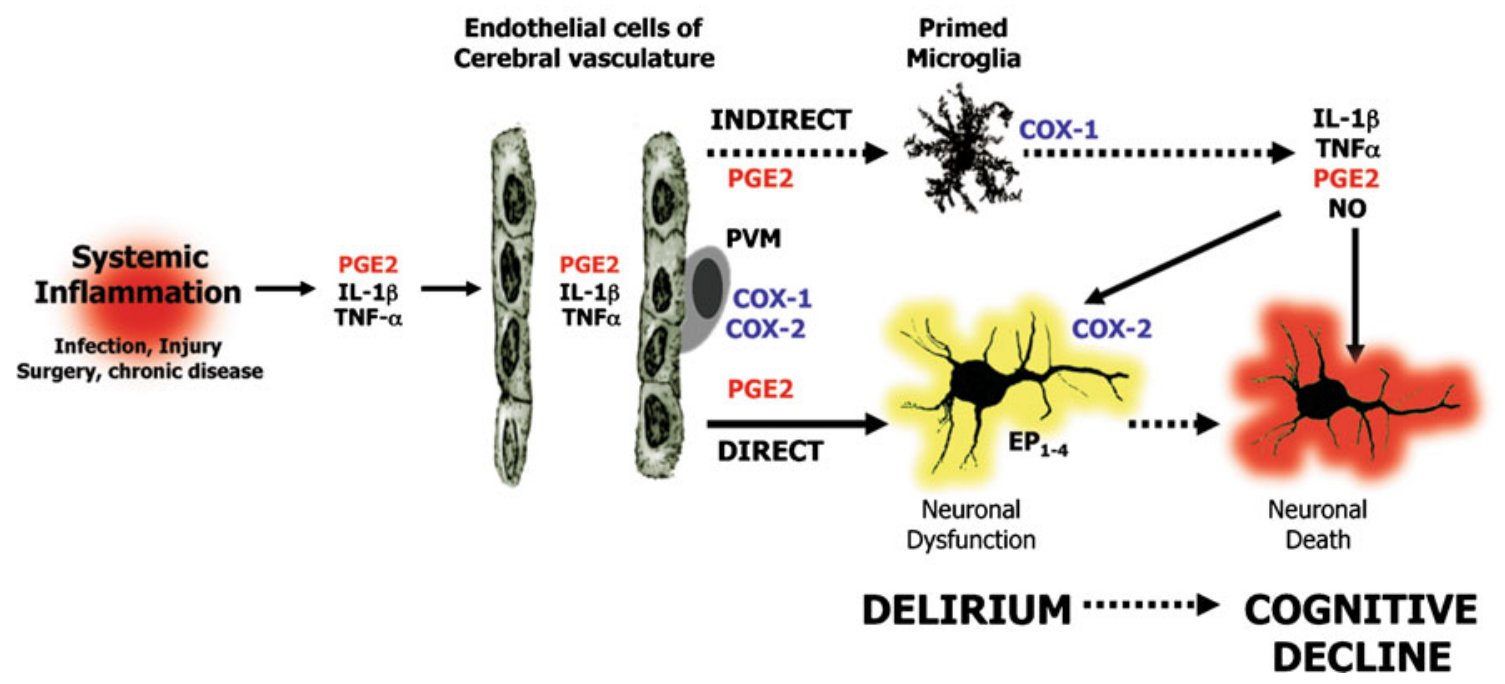

\section{CNS: dementia}

Fig. 4 The role of systemic inflammation in dementia and delirium. Systemic inflammation can influence the progression of dementia and can induce episodes of delirium. We propose that systemic inflammatory mediators, including PGE2, can be released from endothelial, perivascular and microglial cells to influence neuronal function acutely. In addition, local microglial cells, primed by prior pathology, may secrete other inflammatory mediators that contribute to neuronal damage and death. The

COX-1 inhibitor piroxicam protects against this LPS-induced working memory deficit in animals with neurodegeneration while the COX-2-specific inhibitor nimesulide does not. The latter is consistent with evidence that COX-2 inhibition actually exacerbates the CNS consequences of systemic inflammation (Blais et al. 2005) while the former is congruent with our observation of up-regulation of COX-1 in both microglia and PVMs during disease progression (Skelly \& Cunningham, unpublished data) and the recently described role of COX-1-positive PVMs as transducers of systemic inflammatory signals to the brain (Garcia-Bueno et al. 2009). Thus, an amplification of the prostaglandin system in microglia and PVMs may be a key facet of this susceptibility of aging and/or neurodegeneration. Inhibition of COX-1 may be more attractive than inhibition of COX-2 for both physiological and inflammatory reasons. It is striking that the COX-1 inhibition reported in our recent studies reduced PGE2 levels but did not lead to any reduction of blood or brain IL-1 $\beta$, TNF- $\alpha$, IL-6 or CXCL1 (mouse homolog of IL-8), all of which were previously associated with delirium in clinical studies. Levels of prostaglandins have never been measured in studies of delirium and the role of the cyclooxygenase pathway should be investigated in this population. Given the wide array of prostanoids arising from COX activity (Fig. 3) and the side effects that can be associated with COX inhibitors it will be important to be as precise as possible about which elements of these pathways one might want to inhibit. In this pathways for acute dysfunction and those for damage and death may be distinct from each other or may overlap significantly. The inflammatory mediators shown are not intended to constitute an exhaustive list. PGE2: prostaglandin E2, PVM: perivascular macrophage, COX: cyclooxygenase, EP1-4: prostaglandin receptors 1 to 4, NO: nitric oxide, IL-1 $\beta$ : interleukin $1 \beta$, TNF- $\alpha$ : tumor necrosis- $\alpha$

light, further information on the prostanoid receptors involved in this process will also be extremely important.

\section{CNS physiological and pathological roles of prostanoid receptors}

PGE2 signals through the EP receptors 1-4 (Andreasson 2010). The discrete roles for different prostaglandin receptors are currently an area of considerable research activity and a nonexhaustive list of relevant studies have been summarised in Table 1. Perhaps the most clearly defined role for any of the EPs is EP3, which is responsible for temperature regulation and in the generation fever (Ushikubi et al. 1998; Lazarus et al. 2007) and it appears to be the most highly expressed prostaglandin receptor in the brain (Sugimoto and Narumiya 2007). EP3 has also been hypothesized to be involved in acute cognitive impairments via decreased BDNF transcription (Hein and O'Banion 2009), but direct evidence that EP3 is involved remains limited at this point.

Physiologically, EP1 receptors have an important role in activation of the hypothalamic pituitary axis (HPA) (Matsuoka et al. 2003) and have been shown to have a role in dopamine signalling in the striatum (Matsuoka et al. 2005; Kitaoka et al. 2007). However, EP1 is also thought to mediate neurotoxic effects in ischemia/excitotoxicity since EP1 inhibition or deletion typically results in neuroprotec- 
Table 1 CNS physiological and pathological roles of EP receptors

\begin{tabular}{|c|c|c|}
\hline Receptor & Putative functions & References \\
\hline \multirow[t]{3}{*}{ EP1 } & Mediates LPS-induced HPA axis activation & Matsuoka et al. 2003 \\
\hline & Promotes dopaminergic signalling in the striatum & Matsuoka et al. 2005; Kitaoka et al. 2007 \\
\hline & $\begin{array}{l}\text { Participates in control of impulsive behaviour } \\
\text { Contributes to neurotoxic effects following excitotoxic } \\
\text { insult and ischemic brain damage (via improved } \\
\mathrm{Ca}^{2+} \text { signaling and vasoconstriction) }\end{array}$ & Matsuoka et al. 2005; Kawano et al. 2006; Ahmad et al. 2006a \\
\hline \multirow[t]{4}{*}{ EP2 } & $\begin{array}{l}\text { Promotes synaptic plasticity via increases in the amplitude } \\
\text { of hippocampal stimulus-evoked EPSPs }\end{array}$ & Sang et al. 2005 \\
\hline & Neuroprotective in models of stroke/excitotoxicity & McCullough et al. 2004; Liu et al. 2005; Ahmad et al. 2006b \\
\hline & Contributes to amyloid load and oxidative damage in APP/PS1 & Liang et al. 2005 \\
\hline & Hampers phagocytosis and mediates neurotoxicity & Shie et al. 2005 \\
\hline \multirow[t]{2}{*}{ EP3 } & Mediates temperature response to PGE2, LPS and IL-1 $\beta$ & Ushikubi et al. 1998; Lazarus et al. 2007 \\
\hline & Mediates LPS-induced HPA axis activation; & Matsuoka et al. 2003 \\
\hline \multirow[t]{4}{*}{ EP4 } & $\begin{array}{l}\text { Promotes synaptic plasticity via increases in the amplitude } \\
\text { of hippocampal stimulus-evoked EPSPs }\end{array}$ & Sang et al. 2005 \\
\hline & Mediates cerebral vasoconstriction & Maubach et al. 2009 \\
\hline & Limits LPS-induced pro-inflammatory cytokine synthesis & Shi et al. 2010 \\
\hline & $\begin{array}{l}\text { Mediates PGE2-induced wakefulness via activation } \\
\text { of the histaminergic system }\end{array}$ & Huang et al. 2003 \\
\hline
\end{tabular}

tion via neuronal specific mechanisms such as improved $\mathrm{Ca}^{2+}$ homeostasis, (Kawano et al. 2006) and also vasoconstriction (Ahmad et al. 2006a). It may be significant, in this context, that vascular factors such as stroke disease, diabetes mellitus, hypertension and hypotension increase the risk of Alzheimer's Disease (Breteler 2000; Kivipelto et al. 2001; Vermeer et al. 2003; de la Torre 2004). These studies and further evidence that $\mathrm{COX}-2$ and downstream prostaglandin receptors contribute to ischemic brain damage (Nogawa et al. 1997; Iadecola et al. 2001; Kawano et al. 2006) suggest an important link between ongoing ischemic events, prostaglandins and cognitive decline.

As discussed above, EP2 and possibly EP4 in hippocampal neurons have a role in synaptic plasticity whereby post synaptic COX-2/mPGES1 make PGE2 which is released during activity to act on presynaptic EP2/EP4 to increase excitability (Sang et al. 2005). Consistent with this, EP2 appears to be largely neuroprotective in stroke/ excitotoxicity (McCullough et al. 2004; Liu et al. 2005; Ahmad et al. 2006b). However, there are a number of studies suggesting that microglial EP2 contributes to amyloid load and oxidative damage in the APP/PS1 model (Liang et al. 2005), and both hampers microglial phagocytosis and contributes to neurotoxicity (Shie et al. 2005). Conversely, EP4 has recently been described to have an anti-inflammatory role, limiting pro-inflammatory cytokine synthesis induced by LPS (Shi et al. 2010). Although pharmacological studies suggest that EP4 has a role in cerebral vasoconstriction (Maubach et al. 2009) and in promoting wakefulness (Huang et al. 2003), studies of EP4 function have been limited by the poor viability of EP4-/mice, suggesting a key developmental role in the cardiovascular system (Nguyen et al. 1997).

There are, therefore, clear beneficial and deleterious roles for most of the EP receptors and any aspiration to inhibit the function of these receptors, particularly EP2, will have to balance this inhibition with the important physiological roles they serve. In addition to the 4 EP receptors, there are also receptors for PGD2, PGI2, and PGF2a and these have been very little studied in AD although it has been shown that prostaglandin D synthase and the receptor DP1 show increased expression in AD brains and in the Tg2576 AD model (Mohri et al. 2007). Given that inhibition of COX will reduce levels of all of these prostanoids, characterization of these enzymes and receptors in $\mathrm{AD}$ is also necessary.

\section{The future of $\mathrm{COX}$ inhibition in AD}

Despite the two decades that have passed since the discovery that NSAIDs protect against subsequent development of $\mathrm{AD}$, the expression and roles of COX-1, COX-2, PG synthases and $\mathrm{PG}$ receptors in $\mathrm{AD}$ models and patients have still not been adequately characterized. Given that NSAID clinical trials typically inhibit an entire system of physiologically active arachidonic acid metabolites, it is perhaps unsurprising that the results have been confusing and sometimes contradictory. Clinical trials with COX-2 inhibition have failed to show benefits and possibly even increased conversion to AD (Aisen 
et al. 2008) and one recent randomised placebo-controlled clinical trial shows that the COX-1 selective inhibitor Triflusal significantly reduces the rate of conversion from amnestic mild cognitive impairment to dementia (Gomez-Isla et al. 2008). The possibility that COX-1 is a more appropriate target than COX-2 has not been given sufficient consideration. The ADAPT trial reported that both the non-selective inhibitor naproxen and the COX-2-specific celecoxib failed to prevent the development of AD (Martin et al. 2008). Follow up of these patients suggests that the non-selective naproxen, but not celecoxib, is protective but only if patients were cognitively normal at the outset of the study and are observed for 3 years or more (Breitner et al. 2011). Further analysis suggests that naproxen may show deleterious effects, while celecoxib may be protective, if patients are already in a period of steep decline at the time of treatment (Leoutsakos et al. 2011). Thus it seems plausible that there is a long temporal window in which NSAIDs, particularly non-selective or even COX-1 selective drugs, may be effective in slowing $\mathrm{AD}$ development. However, these drugs may become deleterious in later stages of disease, when inflammation is more pronounced, cognitive reserve is more diminished and inhibition of one or both COX isoforms may interfere with crucial physiological functions. However, we do not yet have the data to state this with confidence. The emerging data on the negative impact of systemic inflammation on $\mathrm{AD}$ progression and the implication of $\mathrm{COX}-1$, or indeed cytokines such as IL- $1 \beta$ and TNF- $\alpha$, in this process requires considerably more investigation. Finally the eligibility criteria of future randomised $\mathrm{AD}$ clinical trials must be carefully considered to ensure that we do not exclude patients with co-morbid systemic inflammation, who might finally demonstrate that interfering with inflammation during $\mathrm{AD}$, whether of systemic or central origin, can protect against disease progression.

Disclosure The authors have no conflicts of interest or financial disclosures to make.

Funding Colm Cunningham is supported by the Wellcome trust and Donal Skelly is the recipient of a HRB 4-year PhD award.

Open Access This article is distributed under the terms of the Creative Commons Attribution Noncommercial License which permits any noncommercial use, distribution, and reproduction in any medium, provided the original author(s) and source are credited.

\section{References}

Ahmad AS, Saleem S, Ahmad M, Dore S (2006a) Prostaglandin EP1 receptor contributes to excitotoxicity and focal ischemic brain damage. Toxicol Sci 89:265-270
Ahmad AS, Zhuang H, Echeverria V, Dore S (2006b) Stimulation of prostaglandin EP2 receptors prevents NMDA-induced excitotoxicity. J Neurotrauma 23:1895-1903

Aisen PS, Schmeidler J, Pasinetti GM (2002) Randomized pilot study of nimesulide treatment in Alzheimer's disease. Neurology 58:10501054

Aisen PS, Schafer KA, Grundman M, Pfeiffer E, Sano M, Davis KL, Farlow MR, Jin S, Thomas RG, Thal LJ (2003) Effects of rofecoxib or naproxen vs. placebo on Alzheimer disease progression: a randomized controlled trial. JAMA 289:2819-2826

Aisen PS, Thal LJ, Ferris SH, Assaid C, Nessly ML, Giuliani MJ, Lines CR, Norman BA, Potter WZ (2008) Rofecoxib in patients with mild cognitive impairment: further analyses of data from a randomized, double-blind, trial. Curr Alzheimer Res 5:73-82

Andreasson K (2010) Emerging roles of PGE2 receptors in models of neurological disease. Prostag Other Lipid Mediat 91:104-112

Andreasson KI, Savonenko A, Vidensky S, Goellner JJ, Zhang Y, Shaffer A, Kaufmann WE, Worley PF, Isakson P, Markowska AL (2001) Age-dependent cognitive deficits and neuronal apoptosis in cyclooxygenase-2 transgenic mice. J Neurosci. 21(20):81988209

APA (1994) Diagnostic and Statistical Manual of Mental Disorders (DSM-IV). American Psychiatry Association, Washington

Ashe KH, Zahs KR (2010) Probing the biology of Alzheimer's disease in mice. Neuron 66:631-645

Bannerman DM, Yee BK, Good MA, Heupel MJ, Iversen SD, Rawlins JN (1999) Double dissociation of function within the hippocampus: a comparison of dorsal, ventral, and complete hippocampal cytotoxic lesions. Behav Neurosci 113:1170-1188

Bannerman DM, Deacon RM, Offen S, Friswell J, Grubb M, Rawlins JN (2002) Double dissociation of function within the hippocampus: spatial memory and hyponeophagia. Behav Neurosci 116:884-901

Barnes P, Hale G, Good M (2004) Intramaze and extramaze cue processing in adult APPSWE Tg2576 transgenic mice. Behav Neurosci 118:1184-1195

Barrientos RM, Frank MG, Hein AM, Higgins EA, Watkins LR, Rudy JW, Maier SF (2009) Time course of hippocampal IL-1 beta and memory consolidation impairments in aging rats following peripheral infection. Brain Behav Immun 23:46-54

Beloosesky Y, Hendel D, Weiss A, Hershkovitz A, Grinblat J, Pirotsky A, Barak V (2007) Cytokines and C-reactive protein production in hip-fracture-operated elderly patients. J Gerontol A Biol Sci Med Sci 62:420-426

Blais V, Turrin NP, Rivest S (2005) Cyclooxygenase 2 (COX-2) inhibition increases the inflammatory response in the brain during systemic immune stimuli. J Neurochem 95:1563-1574

Bosetti F (2007) Arachidonic acid metabolism in brain physiology and pathology: lessons from genetically altered mouse models. J Neurochem 102:577-586

Breitner JC, Baker LD, Montine TJ, Meinert CL, Lyketsos CG, Ashe KH, Brandt J, Craft S, Evans DE, Green RC, Ismail MS, Martin BK, Mullan MJ, Sabbagh M, Tariot PN (2011) Extended results of the Alzheimer's disease anti-inflammatory prevention trial. Alzheimers Dement 7:402-411

Breteler MM (2000) Vascular risk factors for Alzheimer's disease: an epidemiologic perspective. Neurobiol Aging 21:153-160

Brugg B, Dubreuil YL, Huber G, Wollman EE, Delhaye-Bouchaud N, Mariani J (1995) Inflammatory processes induce beta-amyloid precursor protein changes in mouse brain. Proc Natl Acad Sci U S A 92:3032-3035

Burns A, Gallagley A, Byrne J (2004) Delirium. J Neurol Neurosurg Psychiatr 75:362-367

Caccamo A, Oddo S, Tran LX, Laferla FM (2007) Lithium reduces tau phosphorylation but not A beta or working memory deficits in a transgenic model with both plaques and tangles. Am J Pathol 170:1669-1675 
Cacucci F, Yi M, Wills TJ, Chapman P, O'keefe J (2008) Place cell firing correlates with memory deficits and amyloid plaque burden in Tg2576 Alzheimer mouse model. Proc Natl Acad Sci U S A 105:7863-7868

Chapman PF, White GL, Jones MW, Cooper-Blacketer D, Marshall VJ, Irizarry M, Younkin L, Good MA, Bliss TV, Hyman BT, Younkin SG, Hsiao KK (1999) Impaired synaptic plasticity and learning in aged amyloid precursor protein transgenic mice. Nat Neurosci 2:271-276

Chen C, Bazan NG (2005) Endogenous PGE2 regulates membrane excitability and synaptic transmission in hippocampal CA1 pyramidal neurons. J Neurophysiol 93:929-941

Chen J, Buchanan JB, Sparkman NL, Godbout JP, Freund GG, Johnson RW (2008) Neuroinflammation and disruption in working memory in aged mice after acute stimulation of the peripheral innate immune system. Brain Behav Immun 22:301311

Choi SH, Bosetti F (2009) Cyclooxygenase-1 null mice show reduced neuroinflammation in response to beta-amyloid. Aging 1:234 244

Choi SH, Langenbach R, Bosetti F (2008) Genetic deletion or pharmacological inhibition of cyclooxygenase- 1 attenuate lipopolysaccharide-induced inflammatory response and brain injury. FASEB J 22:1491-1501

Choi SH, Aid S, Bosetti F (2009) The distinct roles of cyclooxygenase-1 and -2 in neuroinflammation: implications for translational research. Trends Pharmacol Sci 30:174-181

Cibelli M, Fidalgo AR, Terrando N, Ma D, Monaco C, Feldmann M, Takata M, Lever IJ, Nanchahal J, Fanselow MS, Maze M (2010) Role of interleukin-1beta in postoperative cognitive dysfunction. Ann Neurol 68:360-368

Coma M, Sereno L, Da Rocha-Souto B, Scotton TC, Espana J, Sanchez MB, Rodriguez M, Agullo J, Guardia-Laguarta C, Garcia-Alloza M, Borrelli LA, Clarimon J, Lleo A, Bacskai BJ, Saura CA, Hyman BT, Gomez-Isla T (2010) Triflusal reduces dense-core plaque load, associated axonal alterations and inflammatory changes, and rescues cognition in a transgenic mouse model of Alzheimer's disease. Neurobiol Dis 38:482-491

Combrinck M, Williams J, De Berardinis MA, Warden D, Puopolo M, Smith AD, Minghetti L (2006) Levels of CSF prostaglandin E2, cognitive decline, and survival in Alzheimer's disease. J Neurol Neurosurg Psychiatr 77:85-88

Combs CK, Johnson DE, Karlo JC, Cannady SB, Landreth GE (2000) Inflammatory mechanisms in Alzheimer's disease: inhibition of beta-amyloid-stimulated proinflammatory responses and neurotoxicity by PPARgamma agonists. J Neurosci 20:558-567

Corcoran KA, Lu Y, Turner RS, Maren S (2002) Overexpression of hAPPswe impairs rewarded alternation and contextual fear conditioning in a transgenic mouse model of Alzheimer's disease. Learn Mem 9:243-252

Cowley TR, Fahey B, O'mara SM (2008) COX-2, but not COX-1, activity is necessary for the induction of perforant path long-term potentiation and spatial learning in vivo. Eur J Neurosci 27:29993008

Cunningham C (2011) Systemic inflammation and delirium: important co-factors in the progression of dementia. Biochem Soc Trans 39 (4):945-953

Cunningham C, Sanderson DJ (2008) Malaise in the water maze: untangling the effects of LPS and IL-1beta on learning and memory. Brain Behav Immun 22:1117-1127

Cunningham C, Deacon R, Wells H, Boche D, Waters S, Diniz CP, Scott H, Rawlins JN, Perry VH (2003) Synaptic changes characterize early behavioural signs in the ME7 model of murine prion disease. Eur J Neurosci 17:2147-2155

Cunningham C, Wilcockson DC, Campion S, Lunnon K, Perry VH (2005) Central and systemic endotoxin challenges exacerbate the local inflammatory response and increase neuronal death during chronic neurodegeneration. J Neurosci 25:9275-9284

Cunningham C, Campion S, Lunnon K, Murray CL, Woods JF, Deacon RM, Rawlins JN, Perry VH (2009) Systemic inflammation induces acute behavioral and cognitive changes and accelerates neurodegenerative disease. Biol Psychiatr 65:304312

Davies P, Maloney AJ (1976) Selective loss of central cholinergic neurons in Alzheimer's disease. Lancet 2:1403

De La Torre JC (2004) Is Alzheimer's disease a neurodegenerative or a vascular disorder? data, dogma, and dialectics. Lancet Neurol 3:184-190

Deininger MH, Bekure-Nemariam K, Trautmann K, Morgalla M, Meyermann R, Schluesener HJ (2003) Cyclooxygenase-1 and -2 in brains of patients who died with sporadic Creutzfeldt-Jakob disease. J Mol Neurosci 20:25-30

Dodart JC, Bales KR, Gannon KS, Greene SJ, Demattos RB, Mathis C, Delong CA, Wu S, Wu X, Holtzman DM, Paul SM (2002) Immunization reverses memory deficits without reducing brain abeta burden in Alzheimer's disease model. Nat Neurosci 5:452457

Ek M, Engblom D, Saha S, Blomqvist A, Jakobsson PJ, EricssonDahlstrand A (2001) Inflammatory response: pathway across the blood-brain barrier. Nature 410:430-431

Etminan M, Gill S, Samii A (2003) Effect of non-steroidal antiinflammatory drugs on risk of Alzheimer's disease: systematic review and meta-analysis of observational studies. BMJ 327:128

Fick DM, Agostini JV, Inouye SK (2002) Delirium superimposed on dementia: a systematic review. J Am Geriatr Soc 50:1723-1732

Field R, Campion S, Warren C, Murray C, Cunningham C (2010) Systemic challenge with the TLR3 agonist poly I:C induces amplified IFNalpha/beta and IL-1beta responses in the diseased brain and exacerbates chronic neurodegeneration. Brain Behav Immun 24:996-1007

Filali M, Lalonde R (2009) Age-related cognitive decline and nesting behavior in an APPswe/PS1 bigenic model of Alzheimer's disease. Brain Res 1292:93-99

Fong TG, Jones RN, Shi P, Marcantonio ER, Yap L, Rudolph JL, Yang FM, Kiely DK, Inouye SK (2009) Delirium accelerates cognitive decline in Alzheimer disease. Neurology 72:1570 1575

Frank MG, Barrientos RM, Hein AM, Biedenkapp JC, Watkins LR, Maier SF (2010) IL-1RA blocks E. coli-induced suppression of Arc and long-term memory in aged F344xBN F1 rats. Brain Behav Immun 24:254-262

Frye CA, Walf AA (2008) Effects of progesterone administration and APPswe+PSEN1Deltae9 mutation for cognitive performance of mid-aged mice. Neurobiol Learn Mem 89:17-26

Garcia-Bueno B, Serrats J, Sawchenko PE (2009) Cerebrovascular cyclooxygenase-1 expression, regulation, and role in hypothalamicpituitary-adrenal axis activation by inflammatory stimuli. J Neurosci 29:12970-12981

Glazner KaC, Odero GL, Anema E, Motnenko A, Schapansky J, Grossman D, Oliver DR, Glazner GW, Albensi BC (2010) Strain specific differences in memory and neuropathology in a mouse model of Alzheimer's disease. Life Sci 86:942-950

Godbout JP, Chen J, Abraham J, Richwine AF, Berg BM, Kelley KW, Johnson RW (2005) Exaggerated neuroinflammation and sickness behavior in aged mice following activation of the peripheral innate immune system. FASEB J 19:1329-1331

Gomez-Isla T, Blesa R, Boada M, Clarimon J, Del Ser T, Domenech G, Ferro JM, Gomez-Anson B, Manubens JM, Martinez-Lage JM, Munoz D, Pena-Casanova J, Torres F (2008) A randomized, double-blind, placebo controlled-trial of triflusal in mild cognitive impairment: the TRIMCI study. Alzheimer Dis Assoc Disord 22:21-29 
Good MA, Hale G (2007) The "Swedish" mutation of the amyloid precursor protein (APPswe) dissociates components of objectlocation memory in aged Tg2576 mice. Behav Neurosci 121:1180 1191

Griffin DE, Wesselingh SL, Mcarthur JC (1994) Elevated central nervous system prostaglandins in human immunodeficiency virus-associated dementia. Ann Neurol 35:592-597

Guenther K, Deacon RM, Perry VH, Rawlins JN (2001) Early behavioural changes in scrapie-affected mice and the influence of dapsone. Eur J Neurosci 14:401-409

Hauss-Wegrzyniak B, Dobrzanski P, Stoehr JD, Wenk GL (1998) Chronic neuroinflammation in rats reproduces components of the neurobiology of Alzheimer's disease. Brain Res 780:294-303

Hein AM, O'banion MK (2009) Neuroinflammation and memory: the role of prostaglandins. Mol Neurobiol 40:15-32

Hein AM, Stutzman DL, Bland ST, Barrientos RM, Watkins LR, Rudy JW, Maier SF (2007) Prostaglandins are necessary and sufficient to induce contextual fear learning impairments after interleukin-1 beta injections into the dorsal hippocampus. Neuroscience 150:754-763

Heneka MT, Sastre M, Dumitrescu-Ozimek L, Hanke A, Dewachter I, Kuiperi C, O'banion K, Klockgether T, Van Leuven F, Landreth GE (2005) Acute treatment with the PPARgamma agonist pioglitazone and ibuprofen reduces glial inflammation and Abeta1-42 levels in APPV717I transgenic mice. Brain 128:14421453

Holmes C, Boche D, Wilkinson D, Yadegarfar G, Hopkins V, Bayer A, Jones RW, Bullock R, Love S, Neal JW, Zotova E, Nicoll JA (2008) Long-term effects of Abeta42 immunisation in Alzheimer's disease: follow-up of a randomised, placebo-controlled phase I trial. Lancet $372: 216-223$

Holmes C, Cunningham C, Zotova E, Woolford J, Dean C, Kerr S, Culliford D, Perry VH (2009) Systemic inflammation and disease progression in Alzheimer disease. Neurology 73:768-774

Hoozemans JJ, Rozemuller AJ, Janssen I, De Groot CJ, Veerhuis R, Eikelenboom P (2001) Cyclooxygenase expression in microglia and neurons in Alzheimer's disease and control brain. Acta Neuropathol 101:2-8

Huang ZL, Sato Y, Mochizuki T, Okada T, Qu WM, Yamatodani A, Urade Y, Hayaishi O (2003) Prostaglandin E2 activates the histaminergic system via the EP4 receptor to induce wakefulness in rats. J Neurosci 23:5975-5983

Hyman BT, Van Hoesen GW, Damasio AR, Barnes CL (1984) Alzheimer's disease: cell-specific pathology isolates the hippocampal formation. Science 225:1168-1170

Iadecola $\mathrm{C}$, Niwa $\mathrm{K}$, Nogawa $\mathrm{S}$, Zhao X, Nagayama M, Araki E, Morham S, Ross ME (2001) Reduced susceptibility to ischemic brain injury and N-methyl-D-aspartate-mediated neurotoxicity in cyclooxygenase-2-deficient mice. Proc Natl Acad Sci U S A 98:1294-1299

In 'T Veld BA, Ruitenberg A, Hofman A, Launer LJ, Van Duijn CM, Stijnen T, Breteler MMB, Stricker BHC (2001) Nonsteroidal antiinflammatory drugs and the risk of Alzheimer's disease. New Engl J Med 345:1515-1521

Inouye SK, Van Dyck CH, Alessi CA, Balkin S, Siegal AP, Horwitz RI (1990) Clarifying confusion: the confusion assessment method. A new method for detection of delirium. Ann Intern Med 113:941-948

Iordanova MD, Burnett DJ, Aggleton JP, Good M, Honey RC (2009) The role of the hippocampus in mnemonic integration and retrieval: complementary evidence from lesion and inactivation studies. Eur J Neurosci 30:2177-2189

Kawano T, Anrather J, Zhou P, Park L, Wang G, Frys KA, Kunz A, Cho S, Orio M, Iadecola C (2006) Prostaglandin E2 EP1 receptors: downstream effectors of COX-2 neurotoxicity. Nat Med 12:225-229
King DL, Arendash GW (2002) Behavioral characterization of the Tg2576 transgenic model of Alzheimer's disease through 19 months. Physiol Behav 75:627-642

Kitaoka S, Furuyashiki T, Nishi A, Shuto T, Koyasu S, Matsuoka T, Miyasaka M, Greengard P, Narumiya S (2007) Prostaglandin E2 acts on EP1 receptor and amplifies both dopamine D1 and D2 receptor signaling in the striatum. J Neurosci 27:12900-12907

Kitazawa M, Oddo S, Yamasaki TR, Green KN, Laferla FM (2005) Lipopolysaccharide-induced inflammation exacerbates tau pathology by a cyclin-dependent kinase 5 -mediated pathway in a transgenic model of Alzheimer's disease. J Neurosci 25:88438853

Kivipelto M, Helkala EL, Laakso MP, Hanninen T, Hallikainen M, Alhainen K, Soininen $\mathrm{H}$, Tuomilehto J, Nissinen A (2001) Midlife vascular risk factors and Alzheimer's disease in later life: longitudinal, population based study. BMJ 322:1447-1451

Kotilinek LA, Bacskai B, Westerman M, Kawarabayashi T, Younkin L, Hyman BT, Younkin S, Ashe KH (2002) Reversible memory loss in a mouse transgenic model of Alzheimer's disease. J Neurosci 22:6331-6335

Kotilinek LA, Westerman MA, Wang Q, Panizzon K, Lim GP, Simonyi A, Lesne S, Falinska A, Younkin LH, Younkin SG, Rowan M, Cleary J, Wallis RA, Sun GY, Cole G, Frautschy S, Anwyl R, Ashe KH (2008) Cyclooxygenase-2 inhibition improves amyloid-betamediated suppression of memory and synaptic plasticity. Brain 131:651-664

Kukar T, Prescott S, Eriksen JL, Holloway V, Murphy MP, Koo EH, Golde TE, Nicolle MM (2007) Chronic administration of R-flurbiprofen attenuates learning impairments in transgenic amyloid precursor protein mice. BMC Neurosci 8:54

Landreth GE, Heneka MT (2001) Anti-inflammatory actions of peroxisome proliferator-activated receptor gamma agonists in Alzheimer's disease. Neurobiol Aging 22:937-944

Landreth G, Jiang Q, Mandrekar S, Heneka M (2008) PPARgamma agonists as therapeutics for the treatment of Alzheimer's disease. Neurotherapeutics 5:481-489

Lazarus M, Yoshida K, Coppari R, Bass CE, Mochizuki T, Lowell $\mathrm{BB}$, Saper CB (2007) EP3 prostaglandin receptors in the median preoptic nucleus are critical for fever responses. Nat Neurosci 10:1131-1133

Lee DC, Rizer J, Selenica ML, Reid P, Kraft C, Johnson A, Blair L, Gordon MN, Dickey CA, Morgan D (2010) LPS- induced inflammation exacerbates phospho-tau pathology in rTg4510 mice. J Neuroinflamm 7:56

Lehmann JM, Lenhard JM, Oliver BB, Ringold GM, Kliewer SA (1997) Peroxisome proliferator-activated receptors alpha and gamma are activated by indomethacin and other non-steroidal anti-inflammatory drugs. J Biol Chem 272:3406-3410

Leoutsakos JM, Muthen BO, Breitner JC, Lyketsos CG, For the ADAPT Research Team (2011) Effects of non-steroidal anti-inflammatory drug treatments on cognitive decline vary by phase of pre-clinical Alzheimer disease: findings from the randomized controlled Alzheimer's disease anti-inflammatory prevention trial. Int J Geriatr Psychiatr. doi:10.1002/gps.2723

Liang X, Wang Q, Hand T, Wu L, Breyer RM, Montine TJ, Andreasson K (2005) Deletion of the prostaglandin E2 EP2 receptor reduces oxidative damage and amyloid burden in a model of Alzheimer's disease. J Neurosci 25:10180-10187

Lim GP, Yang F, Chu T, Chen P, Beech W, Teter B, Tran T, Ubeda O, Ashe KH, Frautschy SA, Cole GM (2000) Ibuprofen suppresses plaque pathology and inflammation in a mouse model for Alzheimer's disease. J Neurosci 20:5709-5714

Lim GP, Yang F, Chu T, Gahtan E, Ubeda O, Beech W, Overmier JB, Hsiao-Ashec K, Frautschy SA, Cole GM (2001) Ibuprofen effects 
on Alzheimer pathology and open field activity in APPsw transgenic mice. Neurobiol Aging 22:983-991

Liu D, Wu L, Breyer R, Mattson MP, Andreasson K (2005) Neuroprotection by the PGE2 EP2 receptor in permanent focal cerebral ischemia. Ann Neurol 57:758-761

Lyketsos CG, Breitner JC, Green RC, Martin BK, Meinert C, Piantadosi S, Sabbagh M (2007) Naproxen and celecoxib do not prevent AD in early results from a randomized controlled trial. Neurology 68:1800-1808

Maclullich AM, Ferguson KJ, Miller T, De Rooij SE, Cunningham C (2008) Unravelling the pathophysiology of delirium: a focus on the role of aberrant stress responses. J Psychosom Res 65:229 238

Maclullich AM, Edelshain BT, Hall RJ, De Vries A, Howie SE, Pearson A, Middleton SD, Gillies F, Armstrong IR, White TO, Cunningham C, De Rooij SE, Van Munster BC (2011) Cerebrospinal fluid interleukin-8 levels are higher in people with hip fracture with perioperative delirium than in controls. J Am Geriatr Soc 59:11511153

Martin BK, Szekely C, Brandt J, Piantadosi S, Breitner JC, Craft S, Evans D, Green R, Mullan M (2008) Cognitive function over time in the Alzheimer's Disease Anti-inflammatory Prevention Trial (ADAPT): results of a randomized, controlled trial of naproxen and celecoxib. Arch Neurol 65:896-905

Matousek SB, Hein AM, Shaftel SS, Olschowka JA, Kyrkanides S, O'banion MK (2010) Cyclooxygenase-1 mediates prostaglandin $\mathrm{E}(2)$ elevation and contextual memory impairment in a model of sustained hippocampal interleukin-1beta expression. J Neurochem 114:247-258

Matsumoto Y, Yamaguchi T, Watanabe S, Yamamoto T (2004) Involvement of arachidonic acid cascade in working memory impairment induced by interleukin-1 beta. Neuropharmacology 46:1195-1200

Matsuoka Y, Furuyashiki T, Bito H, Ushikubi F, Tanaka Y, Kobayashi T, Muro S, Satoh N, Kayahara T, Higashi M, Mizoguchi A, Shichi H, Fukuda Y, Nakao K, Narumiya S (2003) Impaired adrenocorticotropic hormone response to bacterial endotoxin in mice deficient in prostaglandin E receptor EP1 and EP3 subtypes. Proc Natl Acad Sci U S A 100:4132-4137

Matsuoka Y, Furuyashiki T, Yamada K, Nagai T, Bito H, Tanaka Y, Kitaoka S, Ushikubi F, Nabeshima T, Narumiya S (2005) Prostaglandin E receptor EP1 controls impulsive behavior under stress. Proc Natl Acad Sci U S A 102:16066-16071

Maubach KA, Davis RJ, Clark DE, Fenton G, Lockey PM, Clark KL, Oxford AW, Hagan RM, Routledge C, Coleman RA (2009) BGC20-1531, a novel, potent and selective prostanoid EP receptor antagonist: a putative new treatment for migraine headache. Br J Pharmacol 156:316-327

Mccullough L, Wu L, Haughey N, Liang X, Hand T, Wang Q, Breyer RM, Andreasson K (2004) Neuroprotective function of the PGE2 EP2 receptor in cerebral ischemia. J Neurosci 24:257-268

Mcgeer PL, Schulzer M, Mcgeer EG (1996) Arthritis and antiinflammatory agents as possible protective factors for Alzheimer's disease: a review of 17 epidemiologic studies. Neurology 47:425432

Mckee AC, Carreras I, Hossain L, Ryu H, Klein WL, Oddo S, Laferla FM, Jenkins BG, Kowall NW, Dedeoglu A (2008) Ibuprofen reduces $\mathrm{A}[\mathrm{beta}]$, hyperphosphorylated tau and memory deficits in Alzheimer mice. Brain Res 1207:225-236

Meagher D (2009) More attention, less confusion: time to lessen the burden of delirium. Int Rev Psychiatr 21:1-3

Melnikova T, Savonenko A, Wang Q, Liang X, Hand T, Wu L, Kaufmann WE, Vehmas A, Andreasson KI (2006) Cycloxygenase-2 activity promotes cognitive deficits but not increased amyloid burden in a model of Alzheimer's disease in a sex-dimorphic pattern. Neuroscience 141(3):1149-1162
Mohri I, Kadoyama K, Kanekiyo T, Sato Y, Kagitani-Shimono K, Saito Y, Suzuki K, Kudo T, Takeda M, Urade Y, Murayama S, Taniike M (2007) Hematopoietic prostaglandin D synthase and DP1 receptor are selectively upregulated in microglia and astrocytes within senile plaques from human patients and in a mouse model of Alzheimer disease. J Neuropathol Exp Neurol 66:469-480

Montine TJ, Sidell KR, Crews BC, Markesbery WR, Marnett LJ, Roberts LJ 2nd, Morrow JD (1999) Elevated CSF prostaglandin E2 levels in patients with probable AD. Neurology 53:1495-1498

Morihara T, Teter B, Yang F, Lim GP, Boudinot S, Boudinot FD, Frautschy SA, Cole GM (2005) Ibuprofen suppresses interleukin1 beta induction of pro-amyloidogenic alpha1-antichymotrypsin to ameliorate beta-amyloid (abeta) pathology in Alzheimer's models. Neuropsychopharmacology 30:1111-1120

Morris RGM, Garrud P, Rawlins JNP, O'keefe J (1982) Place navigation impaired in rats with hippocampal lesions. Nature 297:681-683

Murray C, Sanderson DJ, Barkus C, Deacon RM, Rawlins JN, Bannerman DM, Cunningham C (2010) Systemic inflammation induces acute working memory deficits in the primed brain: relevance for delirium. Neurobiol Aging. doi:10.1016/j.neurobiolaging.2010.04.002

Nguyen M, Camenisch T, Snouwaert JN, Hicks E, Coffman TM, Anderson PA, Malouf NN, Koller BH (1997) The prostaglandin receptor EP4 triggers remodelling of the cardiovascular system at birth. Nature 390:78-81

Nguyen MD, D'aigle T, Gowing G, Julien JP, Rivest S (2004) Exacerbation of motor neuron disease by chronic stimulation of innate immunity in a mouse model of amyotrophic lateral sclerosis. J Neurosci 24:1340-1349

Nogawa S, Zhang F, Ross ME, Iadecola C (1997) Cyclo-oxygenase-2 gene expression in neurons contributes to ischemic brain damage. J Neurosci 17:2746-2755

Perry VH (2010) Contribution of systemic inflammation to chronic neurodegeneration. Acta Neuropathol 120:277-286

Pott Godoy MC, Tarelli R, Ferrari CC, Sarchi MI, Pitossi FJ (2008) Central and systemic IL-1 exacerbates neurodegeneration and motor symptoms in a model of Parkinson's disease. Brain 131:1880-1894

Quinn J, Montine T, Morrow J, Woodward WR, Kulhanek D, Eckenstein F (2003) Inflammation and cerebral amyloidosis are disconnected in an animal model of Alzheimer's disease. J Neuroimmunol 137:32-41

Rahkonen T, Luukkainen-Markkula R, Paanila S, Sivenius J, Sulkava R (2000) Delirium episode as a sign of undetected dementia among community dwelling elderly subjects: a 2 year follow up study. J Neurol Neurosurg Psychiatr 69:519-521

Reed MN, Liu P, Kotilinek LA, Ashe KH (2010) Effect size of reference memory deficits in the Morris water maze in $\operatorname{Tg} 2576$ mice. Behav Brain Res 212:115-120

Reines SA, Block GA, Morris JC, Liu G, Nessly ML, Lines CR, Norman BA, Baranak CC (2004) Rofecoxib: no effect on Alzheimer's disease in a 1-year, randomized, blinded, controlled study. Neurology 62:66-71

Rockwood K, Cosway S, Carver D, Jarrett P, Stadnyk K, Fisk J (1999) The risk of dementia and death after delirium. Age Ageing 28:551556

Sang N, Zhang J, Marcheselli V, Bazan NG, Chen C (2005) Postsynaptically synthesized prostaglandin E2 (PGE2) modulates hippocampal synaptic transmission via a presynaptic PGE2 EP2 receptor. J Neurosci 25:9858-9870

Shankar GM, Walsh DM (2009) Alzheimer's disease: synaptic dysfunction and abeta. Mol Neurodegener 4:48

Sheng JG, Bora SH, Xu G, Borchelt DR, Price DL, Koliatsos VE (2003) Lipopolysaccharide-induced-neuroinflammation increases 
intracellular accumulation of amyloid precursor protein and amyloid beta peptide in APPswe transgenic mice. Neurobiol Dis 14:133-145

Shi J, Johansson J, Woodling NS, Wang Q, Montine TJ, Andreasson K (2010) The prostaglandin E2 E-prostanoid 4 receptor exerts anti-inflammatory effects in brain innate immunity. J Immunol 184:7207-7218

Shie FS, Breyer RM, Montine TJ (2005) Microglia lacking E prostanoid receptor subtype 2 have enhanced abeta phagocytosis yet lack abeta-activated neurotoxicity. Am J Pathol 166:11631172

Skelly D, Cunningham C (unpublished data) Synaptic loss and cyclooxygenase 1 activity combine to induce acute exacerbation of dementia

Sly LM, Krzesicki RF, Brashler JR, Buhl AE, Mckinley DD, Carter DB, Chin JE (2001) Endogenous brain cytokine mRNA and inflammatory responses to lipopolysaccharide are elevated in the Tg2576 transgenic mouse model of Alzheimer's disease. Brain Res Bull 56:581-588

Soininen H, West C, Robbins J, Niculescu L (2007) Long-term efficacy and safety of celecoxib in Alzheimer's disease. Dement Geriatr Cogn Disord 23:8-21

Stewart S, Cacucci F, Lever C (2011) Which memory task for my mouse? a systematic review of spatial memory performance in the Tg2576 Alzheimer's mouse model. J Alzheimers Dis

Sugimoto Y, Narumiya S (2007) Prostaglandin E receptors. J Biol Chem 282:11613-11617

Sung S, Yang H, Uryu K, Lee EB, Zhao L, Shineman D, Trojanowski JQ, Lee VM-Y, Pratico D (2004) Modulation of nuclear factor- $\{$ kappa $\}$ $\mathrm{B}$ activity by indomethacin influences $\mathrm{A}\{$ beta $\}$ levels but not $\mathrm{A}$ \{beta\} precursor protein metabolism in a model of Alzheimer's disease. Am J Pathol 165:2197-2206

Teather LA, Packard MG, Bazan NG (2002) Post-training cyclooxygenase-2 (COX-2) inhibition impairs memory consolidation. Learn Mem 9:41-47

Teeling JL, Cunningham C, Newman TA, Perry VH (2010) The effect of non-steroidal anti-inflammatory agents on behavioural changes and cytokine production following systemic inflammation: implications for a role of COX-1. Brain Behav Immun 24:409 419

Terrando N, Rei Fidalgo A, Vizcaychipi M, Cibelli M, Ma D, Monaco C, Feldmann M, Maze M (2010) The impact of IL-1 modulation on the development of lipopolysaccharide-induced cognitive dysfunction. Crit Care 14:R88

Terry RD, Masliah E, Salmon DP, Butters N, Deteresa R, Hill R, Hansen LA, Katzman R (1991) Physical basis of cognitive alterations in Alzheimer's disease: synapse loss is the major correlate of cognitive impairment. Ann Neurol 30:572-580

Tomlinson BE, Irving D, Blessed G (1981) Cell loss in the locus coeruleus in senile dementia of Alzheimer type. J Neurol Sci 49:419-428

Uchikado H, Akiyama H, Kondo H, Ikeda K, Tsuchiya K, Kato M, Oda T, Togo T, Iseki E, Kosaka K (2004) Activation of vascular endothelial cells and perivascular cells by systemic inflammation-an immunohistochemical study of postmortem human brain tissues. Acta Neuropathol 107:341-351

Ushikubi F, Segi E, Sugimoto Y, Murata T, Matsuoka T, Kobayashi T, Hizaki H, Tuboi K, Katsuyama M, Ichikawa A, Tanaka T,
Yoshida N, Narumiya S (1998) Impaired febrile response in mice lacking the prostaglandin E receptor subtype EP3. Nature 395:281284

Van Munster BC, Korevaar JC, Zwinderman AH, Levi M, Wiersinga WJ, De Rooij SE (2008) Time-course of cytokines during delirium in elderly patients with hip fractures. J Am Geriatr Soc 56:1704-1709

Van Munster BC, Bisschop PH, Zwinderman AH, Korevaar JC, Endert E, Wiersinga WJ, Van Oosten HE, Goslings JC, De Rooij SE (2010) Cortisol, interleukins and S100B in delirium in the elderly. Brain Cogn 74:18-23

Vermeer SE, Prins ND, Den Heijer T, Hofman A, Koudstaal PJ, Breteler MM (2003) Silent brain infarcts and the risk of dementia and cognitive decline. N Engl J Med 348:1215-1222

Villaran RF, Espinosa-Oliva AM, Sarmiento M, De Pablos RM, Arguelles S, Delgado-Cortes MJ, Sobrino V, Van Rooijen N, Venero JL, Herrera AJ, Cano J, Machado A (2010) Ulcerative colitis exacerbates lipopolysaccharide-induced damage to the nigral dopaminergic system: potential risk factor in Parkinson's disease. J Neurochem 114:1687-1700

Vlad SC, Miller DR, Kowall NW, Felson DT (2008) Protective effects of NSAIDs on the development of Alzheimer disease. Neurology 70:1672-1677

Walsh DM, Klyubin I, Fadeeva JV, Cullen WK, Anwyl R, Wolfe MS, Rowan MJ, Selkoe DJ (2002) Naturally secreted oligomers of amyloid beta protein potently inhibit hippocampal long-term potentiation in vivo. Nature 416:535-539

Weggen S, Eriksen JL, Das P, Sagi SA, Wang R, Pietrzik CU, Findlay KA, Smith TE, Murphy MP, Bulter T, Kang DE, Marquez-Sterling N, Golde TE, Koo EH (2001) A subset of NSAIDs lower amyloidogenic Abeta42 independently of cyclooxygenase activity. Nature 414:212-216

Weggen S, Rogers M, Eriksen J (2007) NSAIDs: small molecules for prevention of Alzheimer's disease or precursors for future drug development? Trends Pharmacol Sci 28:536-543

Whitehouse PJ, Price DL, Clark AW, Coyle JT, Delong MR (1981) Alzheimer disease: evidence for selective loss of cholinergic neurons in the nucleus basalis. Ann Neurol 10:122-126

Whitehouse PJ, Price DL, Struble RG, Clark AW, Coyle JT, Delon MR (1982) Alzheimer's disease and senile dementia: loss of neurons in the basal forebrain. Science 215:1237-1239

WHO (1992) The ICD-10 classification of mental and behavioural disorders. Diagnostic criteria for research. World Health Organisation, Geneva

Wirths O, Bayer TA (2010) Neuron loss in transgenic mouse models of Alzheimer's disease. Int J Alzheimers Dis. doi:10.4061/2010/ 723782

Yan Q, Zhang J, Liu H, Babu-Khan S, Vassar R, Biere AL, Citron M, Landreth G (2003) Anti-inflammatory drug therapy alters betaamyloid processing and deposition in an animal model of Alzheimer's disease. J Neurosci 23:7504-7509

Yasojima K, Schwab C, Mcgeer EG, Mcgeer PL (1999) Distribution of cyclooxygenase- 1 and cyclooxygenase- 2 mRNAs and proteins in human brain and peripheral organs. Brain Res 830:226-236

Yermakova AV, Rollins J, Callahan LM, Rogers J, O'banion MK (1999) Cyclooxygenase-1 in human Alzheimer and control brain: quantitative analysis of expression by microglia and CA3 hippocampal neurons. J Neuropathol Exp Neurol 58:1135-1146 